\title{
日本に於ける海岸線の曲率に就いて
}

神田清

涩洲國中央数象壱

On the Curvature of Shore-lines in Japan

By Kiyosi Kanda

\section{1. 緒苗}

海岸線は所により雬く、雜多の形を呈してるるが，その內でも砂溜の海岸 線が平滑であるてとは一般に認められてわることである。この小篇は海岸 線の形狀の數字的計算の第一步として日本附近の砂濱を調べるために，陸 地测量部の五萬分之一の地圖によりその曲率牛徑を計算し, それに䦔し 二,三調べを結果を記したものである。

\section{2. 調 查の方 法}

この論文で取扱つた範㘣は日本內地（本州，九州，四國及北海道）の砂 演でその長さが $5 \mathrm{~km}$ 以上のものに限つた。最初先づ二十萬分之一帝國圖 により $5 \mathrm{~km}$ 以上の平滑な砂濱を選び，次に之を五萬分之一地形圖により 海岸地形を吟味しつつ幾分取捨を行ひ，次の方法により曲率牛徑を計算し た。

先づ地圖を振げ海岸線上飞一點 $A$ をとり其兩側に等距離に $B, C$ を取 り $A$ から $B C$ K下した重線の足を $D$ とすれば，海岸線の平滑な場合に は $A$ 點に於ける曲率半徑 $R$ は炏の式で表はすことが出來る。

$$
R=\frac{\overline{A B}^{2}}{2 \cdot \overline{A D}}=\frac{a^{2}}{2 b} \quad(\text { 但 } \overline{A B}=a, \overline{A D}=b)
$$

$a, b$ の值を圖上で求めればての式に依り $R$ を求めることが出來るのであ る。計算に際しては砂濱の長さ (l) が $10 \mathrm{~km}$ 以下のるのに對しては $a=$ $2 \mathrm{~km}, 10 \mathrm{~km}$ 乃至 $40 \mathrm{~km}$ のものに對しては $a=4 \mathrm{~km}$, それ以上のものに 對しては $a=8 \mathrm{~km}$ を探用し, 一つの砂濱上の一個乃至數個の地點に於て $a, b$ を求め $R$ を算出した。 
第 1 表

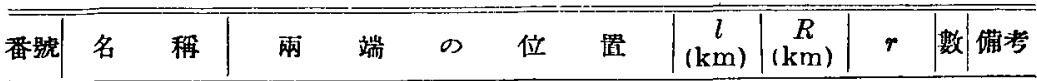

太平洋岸

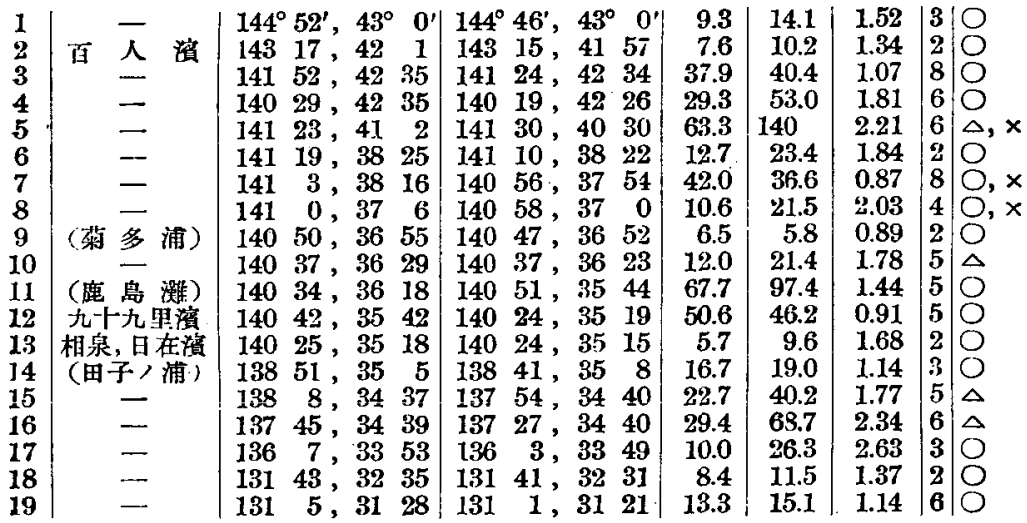

日 本 游岸。

\begin{tabular}{|c|c|c|c|c|c|c|c|c|c|}
\hline 1 & - & $144^{\circ} 48^{\prime}$ & $43^{\circ} 56^{\prime}$ & $144^{\circ} 18^{\prime}, 43^{\circ} 59^{\prime}$ & 40.0 & 43.6 & 1.09 & 9 & $\Delta$ \\
\hline 2 & - & 1445 , & 447 & 14322,4420 & 62.5 & 132 & 2.11 & 6 & $\Delta$ \\
\hline & - & 14135 & 45 & 14148,4438 & 49.9 & 124 & 2.48 & 5 & 0 \\
\hline & - & 14122 & 4316 & $141 \quad 10,439$ & 21.2 & 49.1 & 2.32 & 4 & $\Delta$ \\
\hline & & 14032 & 432 & 14031,4259 & 5.4 & 8.1 & 1.65 & 1 & 0 \\
\hline & & 14034 , & 41 & 14015,4048 & 31.0 & 61.2 & 1.97 & 6 & $\Delta$ \\
\hline & & 140 & 4020 & 13952,3959 & 47.1 & 83.8 & 1.18 & 4 & $\Delta$ \\
\hline & & 13955 & 3954 & $140,3,3946$ & 19.8 & 21.1 & 1.07 & 3 & $\Delta$ \\
\hline & & 13926 & $38 \quad 11$ & 9,3758 & 35.4 & 41.3 & 1.17 & 7 & $\Delta$ \\
\hline & & 13824 & $37 \quad 17$ & $138 \quad 15,37 \quad 11$ & 18.3 & 89.7 & 4.90 & 3 & $\Delta$ \\
\hline & & 13646 & 3654 & $\mathbf{1 3 6} \mathbf{2 9}, \mathbf{3 6} \mathbf{3 0}$ & 52.7 & 142 & 2.69 & 5 & $\Delta$ \\
\hline & & 13628 , & $36 \quad 29$ & $\begin{array}{lllll}136 & 19 & 36 & 21\end{array}$ & 20.4 & 45.0 & 2.21 & 4 & $\Delta$ \\
\hline & 夜見 & 13322, & 3528 & 13315,3532 & 15.1 & 11.9 & 0.79 & 3 & 0 \\
\hline & 新 宮 & 13028 & 3347 & 13025 , & 8.7 & 6.5 & 0.75 & 3 & $\mathrm{O}$ \\
\hline & (敏，中道) & 13025 & 3342 & 13021 , & 7.3 & 10.4 & 1.42 & 2 & 0 \\
\hline & 吹上溜 & 13020 & 3139 & 13018 , & 21.6 & 25.2 & 1.17 & 5 & $\Delta$ \\
\hline
\end{tabular}

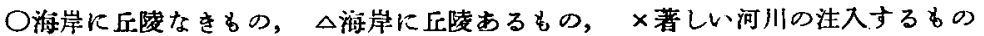

以上述へた方法に依り五萬分之一地形圖加ら求めれ曲率牛徑の值は別表 の通りである。表中第一列は順序の番號を第二列には特別の名稱がある8 のに對して其名を記した。第三列には濱の位置を示すため其网端の概略位

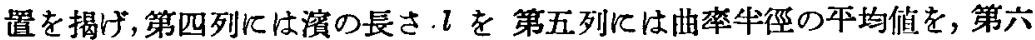
列には $r=R / l=a^{2} / 2 b l$ なる值を記し,第七列には曲率牛徑の平均值を求め るに用みた测點の數を示す。第八列につんては表の借考闌に进へてある。 


\section{3. 曲军半徑と演の展さとの關保}

次に演の曲率牛徑 $R$ と濱の長さ $l$ との關係に就して述へよう。别圆は

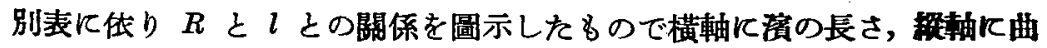
率本徑が取つてある。圖中○は太平洋岸のるの（大きい印は低本在海岸， 小さん印は海岸に゙砂丘及は丘陵の發達したもの)，×壮日本海岸のもの(大 きい印は低平なる海岸，小さい印は海岸に砂丘又は丘陵の發達したるの） を示し，著しい河川が濱に注入するものは○对は区を以て之を示した。

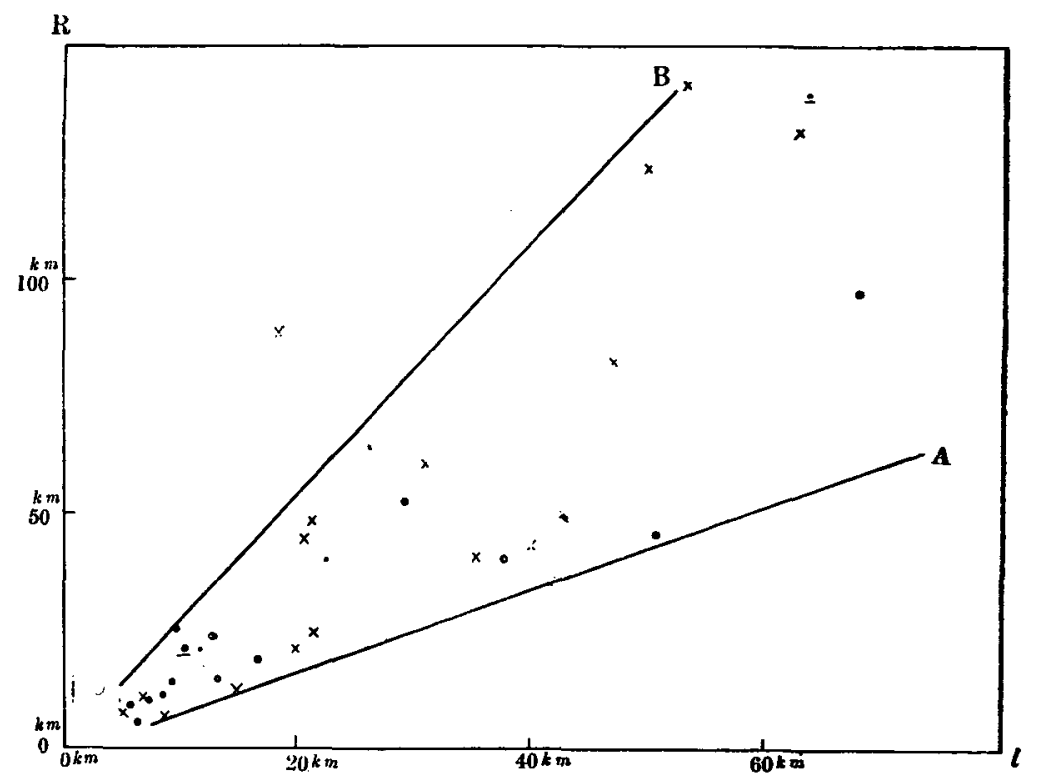

圖を一覧すると次の樣な特徴があるととが判る。郎ち $\boldsymbol{R}$ ととの闑に は大體一定の關係怔あり各點は一つの例外を除き線 $\boldsymbol{A}$ 及線 $\boldsymbol{B}$ の間にあ ろ。今との關係を詳しく調べるためと $l$ の值を五つに區分し各につんて $r=R / l$ の平均值を求めて見た。其結果は

$l$

$10 \mathrm{~km}$ 以下

1.47

$10 \mathrm{~km} \sim 20 \mathrm{~km}$

1.63

$20 \mathrm{~km} \sim 30 \mathrm{~km}$ $l$

$30 \mathrm{~km} \sim 50 \mathrm{~km}$

1.58

$50 \mathrm{~km}$ 以上 
で・の值は $l$ の值によらす略㤘一定であるととが制る。この結果を別の 言葉で云ひ表はせば,

“或ろ濱の曲率牛徑は大顝その演の長さに比例する”

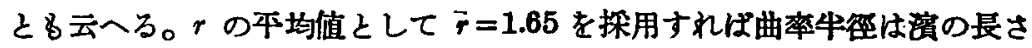
の約 1.65 倍の值をとり, 又圖中の線 $A$ 及線 $B$ からその上限及下限とし て曲率牛徑の值は濱の長さの值の 0.88 倍乃至 2.7 倍でするととが制る。 以上の結果は

“濱を圆弧の一部と見做し得る場合圆の中心が濱の兩端を見込む角は大 凡一定である”

とも言ひ換へるととが出來る。今濱の兩端を見込む角を $\boldsymbol{P}$ とすれば上記 の $\bar{r}$ の值に依り

$$
P=360^{\circ} \times \frac{r}{2 \pi}=34 .{ }^{\circ} 8
$$

で表はされ及 $P$ の取る範圊は上記の場合と同樣に $21^{\circ}$ 乃至 $65^{\circ}$ である ことが制る。

\section{4. 考 察}

大體砂演の形狀を左右すると考へられる原因は次の如くである。

（1）波泿，(2) 潮汐，(3) 海流，(4) 主風向，(5) 海岸の地形，

(6) 土地の昇降，(7) 海岸附近の土壤, 砂磷の性質，(8) 河川の注入

(1)〜(3) は絕えす行はれてわる自然現象でその影響する所は相當大きい タのであらう。殊に波浪の弱い瀨戶內海にはての梳計的調查に該當する樣 な濱を見出し得ない所から見ても（1）の影響は特に大ですると云ひ得る。 及 (4)は風速の特に著しい所では考庶の餘地があり，(5)の地形は上記 (1) 〜(4) と密接な閵係があるもので (1)〜(3) は海岸線附近の垫地の倾斜，(4) に關聯しては海岸線附近に風を遮る山岳の有無，等汃問題となる。(6)の 土地の尔降は地形の大異變のない限り䌝化は少いかも知れないが考虑を要 するととで，(7) の海岸を形成する土壤，砂磷の性質如何でする。及 (8) は當然期待し得ることで例へば仙臺濑には阿武隈川が注入して居る急平滑 を缺してるることは一見して制る。

以上を要するにこの樣な種々の曲率坐徑を左右する原因があるにる拘ら す上記の樣な闑係があるととは若し保件を同じくしたならば前項に迅べた 
より一詹密接な關係が $l$ と $R$ との間にあるととを語るるのではなからう か。

上上本編に述べたてとは何れも多分の想像を含む推察であつて深く調查 してその影響する所をつきとめる必要があると思ふ。

何本篇に於ては $l>5 \mathrm{~km}$ のもののみを調べれがてれより更に小さいる のに就いてての樣なととを調查すれば面白い結果が得られると思はれる。 この場合は附近の地形の影響が相當 $R$ と $l$ との關係に利いて來るととと 思方。

\section{5, 結 語}

以上を要するに平滑なる海岸線の曲率牛徑は濱の長さに大體比例するも のである。ての問題に關する詳細な研究，理論的檢討は地理學に關しては アマチニアである著者の能くする所ではないが，若し諸先輩よりての小篇 几對し御注意御叱正を賜り，及との小篇の結果を檢討せられ，ての方面の 研究を續行せられるならば著者の光榮とする所である。

終に本論文の公表を御許可下さつた谷本中央觀象喜長に深甚の謝意を表 する。 